\title{
PENERAPAN METODE JARIMATIKA DALAM PENINGKATAN HASIL BELAJAR MATEMATIKA SISWA KELAS IV .A MI DDI PALOPO
}

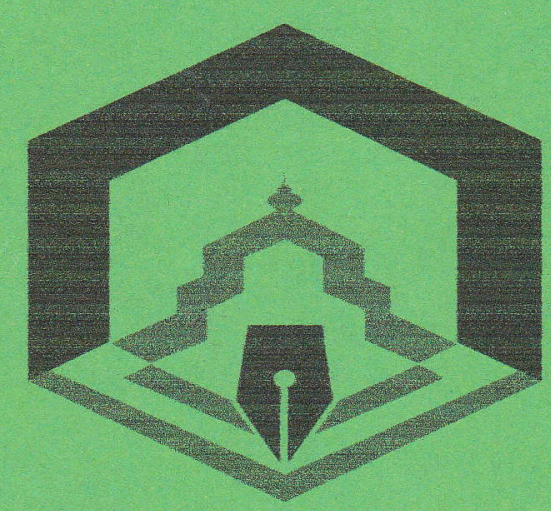

IAIN PALOPO

\section{Tim Peneliti}

$\begin{array}{ll}\text { Ketua Tim } & \text { : Nilam Permatasari, S.Pd., M.Pd } \\ \text { Sekertaris } & \text { : Dra. Nursyamsi, M.Pd } \\ \text { Anggota } & \text { : Nurhabibah } \\ & \text { Harlina M Bakri } \\ & \text { Ildayanti }\end{array}$

INSTITUT AGAMA ISLAM NEGERI PALOPO

(IAIN) PALOPO 


\section{SURAT TUGAS}

Nomor: $138 /$ In.19/FTIK/PP.00.9/09/2016

Dalam rangka melaksanakan tugas penelitian oleh Dosen PGMI, dengan judul penelitian "Penerapan Metode Jarimatika Dalam Meningkatkan Hasil Belajarmatematika Siswa Kelas IV A MI DDI 1 Palopo" maka Dekan FTIK memberi surat tugas kepada:

\begin{tabular}{|c|l|l|}
\hline NO & \multicolumn{1}{|c|}{ NAMA } & \multicolumn{1}{|c|}{ JABATAN } \\
\hline 1 & Nilam Permatasari, S.Pd., M.Pd & Ketua Tim \\
\hline 2 & Dra. Nursyamsi., M.Pd.I & Sekertaris \\
\hline 3 & Nurhabibah & Pembantu Lapangan \\
\hline 4 & Harlina M. Bakri & Pembantu Lapangan \\
\hline 5 & Ildayani & Pengelolah Data \\
\hline
\end{tabular}

Untuk melaksanakan penelitian di Palopo pada hari Selasa, 12 Juli 2016 Demikian, untuk dilaksanakan.

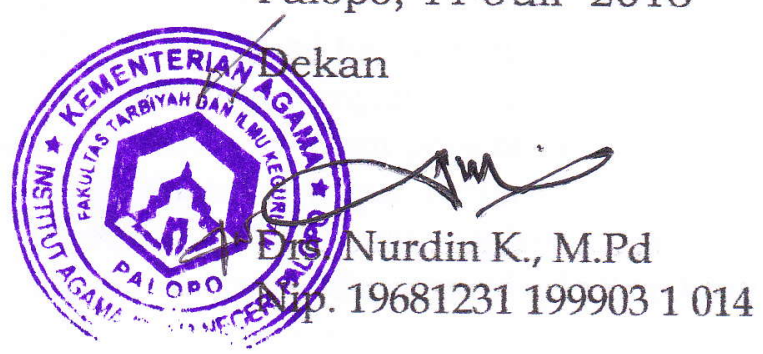




\title{
PENERAPAN METODE JARIMATIKA DALAM PENINGKATAN HASIL BELAJAR MATEMATIKA SISWA KELAS IV.A MI DDI 1 PALOPO
}

\author{
nilampermatasari@iainpalopo.ac.id ${ }^{1)}$ \\ nursyamsi@iainpalopo.ac.id ${ }^{2}$ \\ nurhabibah@gmail.com ${ }^{3)}$ \\ harlina@gmail.com ${ }^{4}$ \\ ildayanti@gmail.com ${ }^{5}$
}

\begin{abstract}
ABSTRAK
Penelitian ini membahas tentang penerapan metode jarimatika dalam meningkatkan hasil belajar matematika siswa materi perkalian pada kelas IVA MI DDI 1 Palopo. Tujuan penelitian ini adalah untuk meningkatkan hasil belajar matematika siswa materi perkalian melalui penggunaan metode jarimatika pada siswa kelas IV.A MI DDI 1 Palopo tahun ajaran 2016/2017. Penelitian ini merupakan Penelitian Tindakan Kelas (PTK) yang dilaksanakan sebanyak dua siklus, tiap siklus dimulai dengan tahapan pelaksanaan yaitu perencanaan (planning), tindakan (action), observasi (observation), dan refleksi (reflection). Masingmasing siklus dilaksanakan sebanyak 2 kali pertemuan. Subjek dalam penelitian ini adalah siswa kelas IV.A MI DDI 1 Palopo pada semester ganjil tahun ajaran 2016/2017 dengan jumlah 27 siswa. Teknik pengumpulan data yang digunakan dalam penelitian ini adalah tes hasil belajar siswa disetiap akhir siklus, observasi selama proses belajar mengajar seperti kehadiran siswa, keaktifan, prestasi hasil belajar, respon terhadap proses pembelajaran dengan penerapan metode jarimatika. Data yang diperoleh selama melakukan penelitian dianalisis menggunakan analisis data deskriptif. Dari hasil analisis diperoleh kesimpulan bahwa dengan penerapan metode jarimatika dapat meningkatkan hasil belajar matematika siswa materi perkalian pada siswa kelas IV.A MI DDI 1 Palopo.
\end{abstract}

\section{Kata Kunci:}

\section{PENDAHULUAN}

Pendidikan dipandang sebagai sarana yang paling tepat dalam rangka mencerdaskan kehidupan bangsa, tidak dapat dipungkiri bahwa maju mundurnya suatu bangsa sangat tergantung pada kualitas sumber daya manusianya. Oleh karena itu diperlukan sebuah format pendidikan yang tepat, efektif, dan efisien untuk mengatasi berbagai kesenjangan pendidikan yang tengah terjadi di negara ini.

Dalam era globalisasi seperti saat ini dunia terasa semakin sempit. Jarak dan ruang yang membatasi antar negara terasa hilang. Arus informasi mengalir cepat seolah tanpa hambatan. Selain itu globalisasi juga telah mengantarkan suasana kehidupan semakin rumit, cepat berubah dan sulit diprediksi. Kondisi ini membawa dampak persaingan yang sangat ketat untuk mendapatkan kehidupan yang layak.

Agar dapat menghadapi derasnya arus globalisasi yang semakin tak terkendali maka pendidikan memiliki peran penting dalam rangka memberi bekal yang cukup pada generasi bangsa saat ini maupun di masa yang akan datang. Oleh karena itu setiap individu harus 
membekali dirinya dengan berbagai kemampuan yang handal yaitu antara lain kemampuan memeroleh, menganalisis, dan mengolah informasi dengan cernat serta kemampuan pemecahan masalah.

Tidak dapat dipungkiri bahwa pendidikan merupakan syarat utama bagi kemajuan suatu bangsa karena pendidikan merupakan sesuatu hal yang harus menjadi prioritas utama dalam rangka mencerdaskan kehidupan berbangsa dan bernegara. Hal ini sesuai dengan fungsi dan tujuan pendidikan Nasional menurut UU No. 20 Tahun 2003 tentang Sistem Pendidikan Nasional (SISDIKNAS) pasal 3 yaitu: "Pendidikan Nasional berfungsi mengembangkan kemampuan dan membentuk watak serta peradaban bangsa, bertujuan untuk berkembangnya potensi siswa agar menjadi manusia yang beriman dan bertakwa kepada Tuhan Yang Maha Esa, berakhlak mulia, sehat, berilmu, cakap, kreatif, mandiri dan menjadi warga negara yang demokrasi dan bertanggung jawab”.

Pendidikan merupakan hal yang penting bagi setiap umat manusia. Islam adalah agama yang membawa misi agar umatnya menyelenggarakan pendidikan dan pengajaran. Al-Qur'an yang pertama kali turun berkenaan dengan masalah keimanan dan masalah pendidikan. Sebagaimana yang tercantum di dalam Q.S. Al-Alaq/96: 1-5:

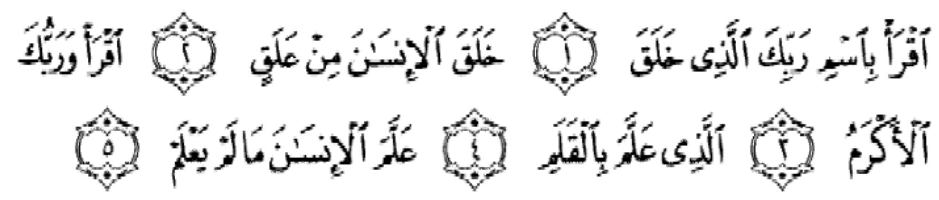

Terjemahnya:

"Bacalah dengan (menyebut) nama Tuhan-mu yang Menciptakan. Dia telah Menciptakan manusia dari segumpal darah. Bacalah, dan Tuhan-mulah Yang Maha Pemurah. Yang Mengajar (manusia) dengan perantaraan kalam. Dia Mengajarkan manusia apa yang tidak diketahuinya".

Dalam kegiatan belajar mengajar, peristiwa yang sering terjadi adalah siswa kurang aktif, kurang berpartisipasi, dan tidak punya inisiatif karena gagasan maupun pendapat sering tidak muncal. Hal ini juga saya temukan di salah satu sekolah MI di Polopo tepatnya di MI DDI 1 Palopo terkhusus pada siswa kelas IV.A dimana tempat dan kelas tersebut peneliti pernah melaksanakan Praktek Pengalaman Lapangan (PPL). Berdasarkan hasil pengamatan proses pembelajaran dipengaruhi oleh beberapa faktor yaitu: siswa, kurikulum, tenaga kependidikan, biaya, sarana dan prasarana serta faktor lingkungan. Apabila faktor-faktor tersebut dapat terpenuhi sudah tentu akan memperlancar proses belajar mengajar yang akan menunjang 
pencapaian hasil belajar yang maksimal yang pada akhirnya akan meningkatkan mutu pendidikan.

Berdasarkan uraian diatas, penulis tertarik mengadakan penelitian dengan judul "Meningkatkan Hasil Belajar Matematika Siswa Materi Perkalian Melalui Metode Jarimatika Pada Siswa Kelas IV.A MI DDI 1 Palopo”.

Adapun tujuan dari penelitian yang akan dilakukan ini adalah untuk menjawab permasalahan pokok di atas. Secara rinci tujuan penelitian ini adalah "Untuk meningkatkan hasil belajar matematika siswa materi perkalian melalui penggunaan metode jarimatika pada siswa kelas IV.A MI DDI 1 Palopo".

Hasil penelitian yang akan diteliti ini diharapkan dapat memberikan manfaat yaitu:

\section{Manfaat Teoritis}

Sebagai informasi pembelajaran kontekstual mengenai metode jarimatika dalam meningkatkan hasil belajar matematika materi perkalian pada siswa kelas IV.A MI DDI 1 Palopo.

\section{Manfaat Praktis}

a. Bagi siswa, dari penelitian ini siswa memperoleh pengalaman belajar yang lebih bermakna, sehingga siswa menjadi lebih menguasai dan terampil dalam pembelajaran pemecahan masalah dengan penerapan metode jarimatika sehingga hasil belajar lebih meningkat dalam mata pelajaran matematika materi perkalian.

b. Bagi guru, sebagai bahan pertimbangan dalam menentukan atau memilih metode dan model pembelajaran yang tepat agar dapat meningkatkan profesionalisme dalam menyajikan dan mengembangkan meteri ajar.

c. Bagi sekolah, hasil penelitian ini diharapkan dapat menjadi informasi berharga bagi sekolah untuk mengambil suatu kebijakan yang tepat dalam rangka perbaikan terhadap metode ajar sehingga dapat meningkatkan hasil belajar siswa khususnya dalam mata pelajaran matematika pada materi perkalian.

d. Bagi peneliti, melalui penelitian ini diharapkan dapat lebih mengetahui strategi dan variasi pembelajaran yang dapat meningkatkan dan memperbaiki sistem pembelajaran di kelas sehingga dapat meminimalkan masalah-masalah yang terjadi dalam pembelajaran. Dan sebagai bahan perbandingan bagi peneliti lain yang ingin meneliti penelitian sijenis.

e. Bagi pengembengan ilmu, penelitian ini dapat dijadikan sebagai sumber referensi. 


\section{METODE}

Penelitian ini adalah Penelitian Tindakan Kelas (Classroom Action Research) atau sering kita dengar dengan singkatan PTK, sudah jelas bahwa penelitian ini adalah penelitian kualitatif. Penelitian ini dirancang untuk guru dan siswa agar mampu memecahkan masalah-masalah yang terjadi di kelas dengan adanya partisipasi dan kolaborasi antara peneliti dengan anggota kelompok sasaran dalam hal ini adalah guru dan siswa kelas IV.A MI DDI 1 Palopo yang terdiri dari beberapa siklus N. Tiap siklus dimulai dengan tahapan pelaksanaan yaitu perencanaan (planning), tindakan (action), observasi (observation), dan refleksi (reflection). Setiap tahapan tersebut berfungsi saling menguraikan karena pada masing-masing tahapan meliputi proses penyempurnaan yang harus dilakukan terus menerus sehingga memperoleh hasil yang diinginkan.

Adapun siklus dalam penelitian tindakan kelas yang dipaparkan diatas merujuk pada model Kemmes dan Mc. Taggart, yaitu model spiral. Bila dilihat dari sumber datanya, pengumpulan data dapat menggunakan sumber primer (sumber data yang langsung memberikan data kepada pengumpul data) dan sumber sekunder (sumber yang tidak langsung memberikan data kepada pengumpul data, misalnya; lewat orang lain atau lewat dokumen). Bila dilihat dari cara atau teknik pengumpulan data, teknik pengumpulan data dapat dilakukan dengan observasi, wawancara, kuesioner, dokumentasi dan gabungan keempatnya. Dalam penelitian kualitatif, pengumpulan data dilakukan pada kondisi yang alamiah, sumber data primer, dan teknik pengumpulan data lebih banyak pada observasi berperanserta dan wawancara mendalam.

Sumber data dalam penelitian ini adalah peserta didik kelas IV.A MI DDI 1 Palopo, Kabupaten Luwu tahun ajaran 2016/2017. Jenis data yang didapatkan adalah data kualitatif dan data kuantitatif. Data kuantitatif, diperoleh dari hasil belajar pada akhir setiap siklus dan data kualitatif, diperoleh dari lembar obsevasi dan tanggapan peserta didik.

Adapun yang menjadi subjek penelitian tindakan kelas ini adalah peserta didik kelas IV.A MI DDI 1 Palopo, Kabupaten Luwu tahun ajaran 2016/2017 yang berjumlah 27 orang (15 perempuan dan 12 laki-laki). Teknik pengumpulan data yang dilakukan oleh peneliti dalam penelitian tindakan kelas ini adalah data mengenai tes hasil belajar siswa dikumpulkan setiap akhir siklus dan data mengenai kehadiran siswa, keaktifan belajar siswa, prestasi dalam hasil belajar siswa, respon siswa terhadap proses pembelajaran matematika dengan penerapan metode jarimatika dikumpulkan dengan menggunakan lembar observasi. 
Tahapan sesudah pengumpulan data adalah pengolahan dan analisis data. Dalam penelitian tindakan kelas, analisis dilakukan peneliti sejak awal, setiap aspek kegiatan penelitian dilakukan pencatatan lapangan melaui observasi atau pengamatan tentang kegiatan pembelajaran dikelas, peneliti dapat langsung menganalisis apa yang diamatinya, guru dengan siswa, interkasi antara siswa dengan siswa dan lain sebagainya. Dalam penelitian ini, data yang telah dikumpul dianalisis dengan menggunakan teknik analisis kualitatif dan kuantitatif.

\section{HASIL PENELITIAN DAN PEMBAHASAN}

\section{A. Hasil Penelitian}

\section{Diskripsi Hasil Analisis Siklus I}

Ada beberapa tahap yang dilakukan pada pelaksanaan siklus I yaitu tahap perencanaan, tahap pelaksanaan, tahap observasi dan tahap evaluasi, serta tahap refleksi.

\section{1) Tahap Perencanaan}

Pada tahap ini peneliti mempersiapkan materi-materi dan media yang akan digunakan dan dibahas pada siklus I yaitu pembelajaran dengan menerapkan metode jarimatika materi perkalian, selain itu peneliti membuat perangkat bembelajaran berdasarkan silabus pembelajaran mata pelajaran matematika kelas IV.A semester 1 MI DDI 1 Palopo, dengan materi perkalian dengan menerapkan metode jarimatika untuk setiap kali pertemuan. Selanjutnya peneliti mempersiapkan instrumen pengamatan atau lembar observasi untuk mencatat aspek-aspek aktivitas proses pembelajaran yang dilakukan siswa dalam kegiatan pembelajaran (belajar mengajar), dengan konsep dasar jarimatika dan tentang perkalian jarimatika pada mata pelajaran matematika materi perkalian, serta mendisain bahan evaluasi untuk melihat kemampuan siswa dalam menyelesaikan soal-soal latihan.

\section{2) Tahap Pelaksanaan Tindakan}

Dalam tahap pelaksanaan tindakan ini, peneliti melaksanakan tindakan berdasarkan skenario rencana pembelajaran yang telah disiapkan dan dibuat sebelumnya oleh peneliti untuk melakukan kegiatan pembelajaran matematika materi perkalian dengan penerapan metode jarimatika (Rencana Pelaksanaan Pembelajaran/RPP Terlampir). Peneliti bersama observer memantau dan mengopservasi tindakan yang dilaksanakan dengan menggunakan lembar observasi. Kemudian tiap siklus diadakan tes akhir siklus, dimana disini adalah tes akhir siklus I.

\section{3) Tahap Observasi dan Evaluasi}

\section{Deskripsi Hasil Observasi Aktivitas Siswa}


Memasuki tahap observasi, pada observasi siklus I ini yang menjadi sasaran observasi penelitian adalah aspek-aspek proses pembelajaran yang dilakukan siswa dalam kegiatan pembelajaran, baik itu data hasil penilaian kognitif siswa (tertulis) maupun afektif dan psikomotor siswa (pengamatan). Tahap observasi pada siklus I tercatat sikap yang terjadi pada setiap siswa terhadap mata pelajaran matematika materi perkalian dengan penerapan metode jarimatika. Sikap siswa tersebut diperoleh dari lembar observasi pada setiap pertemuan yang dicatat pada setiap siklus. Lembar observasi tersebut digunakan untuk mengetahui perubahan cara mengajar guru dan sikap siswa selama proses belajar mengajar berlangsung di kelas pada tiap pertemuan. Hasil observasi aktivitas siswa dapat dilihat pada lampiran yang disajikan dalam tabel dibawah ini:

Tabel 1

\section{Hasil Observasi Aktivitas Siswa Kelas IV.A MI DDI 1 Palopo Sebelum Penerapan Metode Jarimatika}

\begin{tabular}{|c|l|c|}
\hline No & \multicolumn{1}{|c|}{ Komponen Yang Diamati } & $\begin{array}{c}\text { Hasil Persentase } \\
\text { Sebelum Penerapan } \\
\text { Metode Jarimatika }\end{array}$ \\
\hline 1 & Siswa yang hadir pada saat proses pembelajaran & $92,59 \%$ \\
\hline 2 & $\begin{array}{l}\text { Siswa yang serius dalam menerima } \\
\text { pembelajaran }\end{array}$ & $55,55 \%$ \\
\hline 3 & $\begin{array}{l}\text { Siswa yang melakukan kegiatan lain pada saat } \\
\text { Pembelajaran }\end{array}$ & $48,15 \%$ \\
\hline 4 & $\begin{array}{l}\text { Siswa yang belum memahami materi yang } \\
\text { diajarkan }\end{array}$ & $74,07 \%$ \\
\hline 5 & $\begin{array}{l}\text { Siswa yang aktif bertanya pada guru mengenai } \\
\text { materi pembelajaran }\end{array}$ & $11,11 \%$ \\
\hline 6 & $\begin{array}{l}\text { Siswa yang aktif membantu temannya dalam } \\
\text { pemecahan masalah mengenai materi } \\
\text { pembelajaran }\end{array}$ & $7,41 \%$ \\
\hline 7 & $\begin{array}{l}\text { Siswa yang mampu mengerjakan dan } \\
\text { menyelesaikan soal-soal latihan }\end{array}$ & $18,52 \%$ \\
\hline 8 & $\begin{array}{l}\text { Siswa yang membutuhkan bimbingan guru } \\
\text { dalam menyelesaikan tugas latihan }\end{array}$ & $74,07 \%$ \\
\hline
\end{tabular}

Adapun deskripsi aktivitas siswa sebelum penerapan metode jarimatika diperoleh bahwa dari 27 siswa kelas IV.A MI DDI 1 Palopo yang ikut dalam pembelajaran diperoleh kehadiran siswa 92,59\%, siswa yang serius dalam menerima pembelajaran 55,55\%, siswa yang melakukan kegiatan lain pada saat pembelajaran $48,15 \%$, siswa yang belum memahami materi yang diajarkan $74,07 \%$, siswa yang aktif bertanya pada guru mengenai materi pembelajaran $11,11 \%$, siswa yang aktif membantu temannya dalam pemecahan masalah mengenai materi 
pembelajaran $7,41 \%$, siswa yang mampu mengerjakan dan menyelesaikan soal-soal latihan $18,52 \%$, siswa yang membutuhkan bimbingan guru dalam menyelesaikan tugas latihan $74,07 \%$. Data hasil belajar sebelum penerapan metode jarimatika dapat dilihat pada lampiran tabel 4.4.

Adapun hasil observasi aktivitas siswa kelas IV.A MI DDI 1 Palopo pada siklus I setelah penerapan metode jarimatika dapat dilihat pada tabel berikut:

Tabel 2

Hasil Observasi Aktivitas Siswa Kelas IV.A MI DDI 1 Palopo Pada Siklus I Setelah Penerapan Metode Jarimatika

\begin{tabular}{|c|l|c|}
\hline No & \multicolumn{1}{|c|}{ Komponen Yang Diamati } & $\begin{array}{c}\text { Hasil Persentase } \\
\text { Siklus I }\end{array}$ \\
\hline 1 & Siswa yang hadir pada saat proses pembelajaran & $96,30 \%$ \\
\hline 2 & Siswa yang serius dalam menerima pembelajaran & $77,78 \%$ \\
\hline 3 & $\begin{array}{l}\text { Siswa yang melakukan kegiatan lain pada saat } \\
\text { Pembelajaran }\end{array}$ & $22,22 \%$ \\
\hline 4 & $\begin{array}{l}\text { Siswa yang belum memahami materi yang } \\
\text { diajarkan }\end{array}$ & $18,51 \%$ \\
\hline 5 & $\begin{array}{l}\text { Siswa yang aktif bertanya pada guru mengenai } \\
\text { materi pembelajaran }\end{array}$ & $33,33 \%$ \\
\hline 6 & $\begin{array}{l}\text { Siswa yang aktif membantu temannya dalam } \\
\text { pemecahan masalah materi metode jarimatika }\end{array}$ & $25,93 \%$ \\
\hline 7 & $\begin{array}{l}\text { Siswa yang mampu mengerjakan dan } \\
\text { menyelesaikan soal-soal latihan }\end{array}$ & $59,30 \%$ \\
\hline 8 & $\begin{array}{l}\text { Siswa yang membutuhkan bimbingan guru dalam } \\
\text { menyelesaikan tugas latihan }\end{array}$ & $40,74 \%$ \\
\hline
\end{tabular}

Adapun deskripsi aktivitas siswa pada siklus I dari 27 siswa kelas IV.A MI DDI 1 Palopo yang masih aktif, diperoleh bahwa kehadiran siswa rata-tara 96,30\%, siswa yang serius dalam menerima pelajaran $77,78 \%$, siswa yang melakukan kegiatan lain pada saat proses pembelajaran $22,22 \%$, siswa yang belum memahami materi yang diajarkan $18,51 \%$, siswa yang aktif bertanya pada guru mengenai materi pembelajaran 33,33\%, siswa yang aktif membantu temannya dalam pemecahan masalah materi metode jarimatika 25,93\%, siswa yang mampu mengerjakan dan menyelesaikan soal-soal latihan 59,30\%, dan siswa yang membutuhkan bimbingan guru dalam menyelesaikan tugas latihan ada 40,74\%.

a) Deskripsi hasil belajar atau evaluasi siswa

Pada siklus I ini dilaksanakan tes hasil belajar di akhir pembelajaran dengan mengerjakan soal-soal latihan yang diberikan oleh peneliti kepada siswa yang mengikuti pembelajaran. Hal ini dilakukan untuk melihat sejauh mana peningkatan hasil belajar 
matematika siswa materi perkalian setelah diterapkannya metode jarimatika. Data hasil belajar siklus I dalam kegiatan pembelajaran materi perkalian setelah penerapan metode jarimatika dapat dilihat pada tabel berikut:

Tabel 3.

Hasil Evaluasi Siklus I Setelah Penerapan Metode Jarimatika

\begin{tabular}{|c|c|c|c|}
\hline \multicolumn{2}{|r|}{ Nomor } & \multirow{2}{*}{ Nama Murid } & \multirow{2}{*}{ Skor } \\
\hline Urut & NIS & & \\
\hline 1 & 111273730001120014 & Muh. Ari Sigit & 80 \\
\hline 2 & 111273730001120024 & Muhammad Ayub & 0 \\
\hline 3 & 111273730001130011 & Bella Vista & 100 \\
\hline 4 & 111273730001130017 & Firman Syahputra Sandy & 0 \\
\hline 5 & 111273730001130020 & Halila & 100 \\
\hline 6 & 111273730001130071 & Ipa Ainun Bilqisti & 60 \\
\hline 7 & 111273730001130027 & Kasmita & 80 \\
\hline 8 & 111273730001130029 & Mariani & 20 \\
\hline 9 & 111273730001130031 & Muh. Abhy & 0 \\
\hline 10 & 111273730001130032 & Muh. Afdal Zul Arsil & 100 \\
\hline 11 & 111273730001130038 & Muh. Isal Sudirman & 100 \\
\hline 12 & 111273730001130073 & Muh. Rahman & 0 \\
\hline 13 & 111273730001130046 & Mustajaab Arrahman & 100 \\
\hline 14 & 111273730001130069 & Multazan Fihil Nizan & 0 \\
\hline 15 & 111273730001130049 & Nur Afni & 80 \\
\hline 16 & 111273730001130050 & Nurfadillah Sari & 80 \\
\hline 17 & 111273730001130051 & Nurul Aulia & 80 \\
\hline 18 & 111273730001130052 & Perawati Safitri & 20 \\
\hline 19 & 111273730001130058 & Rihan Vareza & 100 \\
\hline 20 & 111273730001130061 & Salsabilah & 80 \\
\hline 21 & 111273730001130062 & Sri Rahayu & 80 \\
\hline 22 & 111273730001130063 & St. Nurasyiah & 40 \\
\hline 23 & 111273730001130065 & Syahrul & 100 \\
\hline 24 & 111273730001130077 & Yulia Ramadhani & 100 \\
\hline 25 & 111273730001130072 & Ummul Safna Ihtizan & 60 \\
\hline 26 & 111273730001130082 & Nadine Livhia & 80 \\
\hline 27 & 111273730001130087 & Muh. Ibnu Khaldun Manangalu & 40 \\
\hline
\end{tabular}

Dapat disimpulkan dari tabel 4.8 dan 4.9 diatas dapat diketahui bahwa mulai dari hasil observasi aktivitas siswa dan hasil evaluasi setelah penerapan metode jarimatika pada siklus I diketahui bahwa ada peningkatan pada hasil observasi aktivitas siswa dan hasil evaluasi setelah penerapan metode jarimatika pada siswa kelas IV.A MI DDI 1 Palopo dibanding dengan sebelum penerapan metode jarimatika. Namun dari data diatas terlihat bahwa masih ada 
beberapa siswa yang belum tuntas dalam siklus I ini itu berarti bahwa masih ada beberapa siswa yang belum mencapai nilai ketuntasan atau indikator kerja. Berarti masih banyak siswa yang belum menguasai matematika materi perkalian dengan penerapan metode jarimatika. Data indikator aspek-aspek proses pembelajaran yang dilakukan guru dengan instrumen pengamatan yaitu adalah aspek-aspek proses pembelajaran yang dilakukan guru meliputi perencanaan, kegiatan utama dan pemantapan. Apabila nilai kemampuan awal siswa di kelompokkan dalam lima kategori maka hasil tes siklus I dipaparkan sebagai berikut:

Tabel 4.

Kategorisasi Tes Hasil Belajar Siswa Kelas IV.A MI DDI 1 Palopo Pada Siklus I Setelah Penerapan Metode Jarimatika

\begin{tabular}{|c|c|c|c|}
\hline Rentang Skor & Kategori & Frekuensi & Persentase \\
\hline $0-54$ & Sangat Kurang & 9 & $33,33 \%$ \\
\hline $55-64$ & Kurang & 2 & $7,41 \%$ \\
\hline $65-74$ & Cukup & 0 & $0 \%$ \\
\hline $75-84$ & Baik & 8 & $29,63 \%$ \\
\hline $85-100$ & Sangat Baik & 8 & $29,63 \%$ \\
\hline Jumlah & & $\mathbf{2 7}$ & $\mathbf{1 0 0 \%}$ \\
\hline
\end{tabular}

Berdasarkan tabel diatas dapat kita lihat bahwa jumlah frekuensi sebanyak 27 siswa aktif. Diperoleh bahwa ada sebanyak 9 siswa berada pada kategori Sangat Kurang dengan persentase 33,33\%, 2 siswa berada pada kategori Kurang dengan persentase 7,41\%, tidak ada siswa yang berada dalam kategori Cukup, dan ada sebanyak 8 siswa berada dalam kategori Baik dan Sangat Baik dengan persentase 29,63\%.

Apabila hasil belajar siswa dipaparkan dalam kriteria ketuntasan hasil belajar secara klasikal pada siklus I ini maka dapat dilihat pada table berikut:

Tabel 5

Persentase Ketuntasaan Hasil Belajar Siswa Kelas IV.A MI DDI 1 Palopo Siklus I Setelah Penerapan Metode Jarimatika

\begin{tabular}{|c|c|c|c|}
\hline Rentang Skor & Kategori & Frekuensi & Persentase \\
\hline $65-100$ & Tuntas & 16 & $59,26 \%$ \\
\hline $0-64$ & Tidak Tuntas & 11 & $40,74 \%$ \\
\hline \multicolumn{2}{|r|}{ Jumlah } & $\mathbf{2 7}$ & $\mathbf{1 0 0 \%}$ \\
\hline
\end{tabular}

Tabel $4.11 \mathrm{~d}$ atas menunjukan bahwa dari 27 siswa kelas IV.A MI DDI 1 Palopo yang aktif, terdapat 16 siswa yang tuntas dalam pembelajaran dengan persentase 59,26\% dan masih ada sebanyak 11 siswa yang tidak tuntas dengan persentase 40,74\%. Pada siklus I ini persentase ketuntasan klasikal siswa belum tercapai sehingga dilanjutkan kesiklus selanjutnya. 


\section{1) Tahap Refleksi Siklus I}

Dari keterangan hasil observasi dan evaluasi yang telah di paparkan oleh peneliti dapat di simpulkan bahwa ada peningkatan hasil belajar matematika siswa kelas IV.A MI DDI 1 Palopo setelah diterapkannya pembelajaran dengan menggunakan metode jarimatika dibanding dengan sebelum penerapan metode jarimatika, namun dari hasil data yang telah di paparkan di atas masih kurang dari batas minimal ketuntasan. Itu berarti siswa belum dapat menguasai materi konsep dasar metode jarimatika, oleh karena itu peneliti merasa masih perlu menerapkan tindakan dengan melanjutkan penelitian ke siklus II dengan melakukan berbagai macam perbaikan agar dapat mewujudkan atau mencapai tujuan pembelajaran sesuai dengan judul yang peneliti paparkan pada halaman sampul di depan. Pembelajaran dengan menggunakan metode jarimatika lebih mendorong siswa untuk aktif dalam proses pembelajaran dengan terlibat langsung dalam kegiatan proses belajar mengajar seperti aktif memainkan jari-jari mereka dalam berhitung.

Namun pada saat dilokasi penelitian ada beberapa hambatan yang peneliti rasakan dalam pembahasan materi diantaranya:

a) Ada beberapa siswa yang melakukan kegiatan lain terutama siswa yang duduk di bagian belakang.

b) Hambatan yang terasa lagi adalah adanya perubahan pembelajaran sehingga siswa membutuhkan penyesuaian terhadap pendekatan pembelajaran maupun pengajarannya.

c) Dan hambatan lain yang peneliti temukan di lapangan yaitu adanya kesulitan siswa memahami konsep dasar yang diterapkan oleh peneliti karena berbeda dari pembelajaran yang biasa siswa lakukan.

Dengan alasan tersebut pada tahap refleksi ini, untuk siklus berikutnya peneliti mengubah posisi duduk siswa yang suka melakukan kegiatan lain ke bangku bagian depan agar siswa tidak leluasa melakukan kegiatan lain dan menjadi perhatian peneliti saat penyajian materi. Dalam kegiatan awal pembelajaran dengan penerapan metode jarimatika peneliti membimbing siswa dalam hal cara-cara menghitung dan mengingat simbol-simbol dari jari tangan yang digunakan untuk berhitung, hal ini dilakukan agar pada pertemuan berikutnya semua siswa dapat terlebih dahulu memahami konsep awal dalam berhitung dengan menggunakan metode jarimatika, sehingga pada tahap selanjutnya siswa hanya dilatih untuk terbiasa menggerakkan jarinya agar mereka tidak kaku dalam proses berhitung dengan menggunakan jarinya dan siswa dapat menggabungkan hasil akhir dari penghitungan metode jarimatika. 
Selama proses pembelajaran berhitung dengan mengunakan metode jarimatika berlangsung, interaksi antara siswa terlihat lebih aktif meskipun pada awalnya siswa merasa ketakutan karena tidak mampu melatih jari-jari tangan dan mengingat simbol-simbol dari tiap jarinya. Hal ini disebabkan oleh faktor belum terbiasa oleh karena itu dibutuhkan kesabaran dalam membimbing siswa menemukan sendiri polanya. Pemahaman terhadap konsep dasar metode jarimatika akan membuat siswa tertarik untuk mulai mencobanya, sedikit demi sedikit siswa mulai mampu melatih jari-jarinya dengan baik. Agar proses pembelajaran tidak terasa jenuh dan membosankan peneliti menerapkan model pembelajaran Demonstration dan Expilic Intruction dalam pembelajaran metode jarimatika dan menciptakan sebuah permainan atau game dalam pembelajaran agar meningkatkan minat dan motivasi belajar siswa terhadap pembelajaran matematika. Dalam proses pembelajaran antusias siswa terhadap pelajaran sudah ada perubahan dari pertemuan sebelumnya. Hal ini terlihat dengan semakin bertambahnya siswa yang bertanya mengenai materi dengan penggunaan metode jarimatika yang diterapkan oleh peneliti dalam pembelajaran dengan memberikan hadiah berupa bingkisan alat tulis, snack dan hadiah berupa pujian, terlihat banyaknya siswa yang ingin naik ke depan untuk menyelesaikan soal-soal latihan yang diberikan oleh peneliti.

\section{Deskripsi Hasil Analisis Siklus II}

Hampir sama dengan pelaksanaan siklus I, ada beberapa tahap yang dilakukan pada pelaksanaan siklus II ini yaitu tahap perencanaan, tahap pelaksanaan, tahap observasi dan evaluasi, dan serta tahap refleksi.

\section{1) Tahap Perencanaan Tindakan}

Pada siklus II ini tahap perencanaan hampir sama dengan tahap perencanaan pada tahap sebelumnya yaitu menelaah materi yang akan dibahas selama berlangsungnya siklus II, materi tersebut adalah lanjutan materi sebelumnya dan kemudian peneliti membuat perangkat pembelajaran mulai dari RPP, dan instrumen yang akan digunakan serta membuat lembar observasi yang digunakan untuk mengamati kondisi pembelajaran di kelas IV.A MI DDI 1 Palopo selama proses pembelajaran berlangsung.

2) Tahap Pelaksanaan Tindakan

Tahap pelaksanaan tindakan pada siklus II adalah mengulangi langkah kerja pada siklus I. Tindakan-tindakan pada siklus II lebih dikembangkan dan didasari oleh hasil observasi dan evaluasi serta refleksi pada siklus I. Adapun lanjutan tindakan tersebut dilakukan dengan melaksanakan tindakan berdasarkan rencana pembelajaran berdasarkan siklus II yang telah disiapkan oleh peneliti dengan berupaya memperbaiki kelemahan aspek-aspek pembelajaran yang telah dilakukannya pada siklus I. Pada setiap pertemuan peneliti menjelaskan materi 
sesuai dengan RPP disertai dengan contoh latihan soal-soal yang lebih banyak melibatkan siswa. Selanjutnya peneliti membagikan tugas kepada siswa yang sudah faham dan mengerti mengenai materi untuk mengajar temannya yang masih belum faham dengan dibimbing oleh peneliti dan kemudian diberikan latihan soal kepada siswa yang belum faham untuk mengetahui apakah siswa tersebut sudah dapat memahami materi yang diajarkan oleh temannya. Kemudian semua siswa diberi tugas atau soal latihan untuk diselesaikan dan kemudian dikumpul dan diperiksa dan dikembalikan. Sama seperti siklus I peneliti juga memantau dan mengobservasi tindakan yang dilakukan oleh siswa dengan menggunakan lembar observasi, dan dilakukan tes akhir siklus II.

3) Tahap Observasi dan Evaluasi

a) Deskripsi hasil observasi aktivitas siswa

Selama penelitian terjadi peningkatan hasil belajar matematika siswa materi perkalian setelah diterapkannya metode jarimatika, dengan menggunakan model pembelajaran Demonstration dan Expilic Intruction dalam pembelajaran baik itu kognitif, afektif, serta psikomotoriknya dan tercatat pula sejumlah perubahan yang terjadi pada setiap siswa terhadap pelajaran matematika materi perkalian. Perubahan tersebut diperoleh dari lembar observasi pada setiap pertemuan yang dicatat pada setiap siklus. Lembar observasi tersebut untuk mengetahui perubahan siswa selama proses pembelajaran berlangsung.

Hasil observasi aktivitas siswa pada siklus II dapat dilihat pada tabel berikut ini:

Tabel 6

Hasil Observasi Aktivitas Siswa Kelas IV.A MI DDI 1 Palopo Pada Siklus II Setelah Penerapan Metode Jarimatika

\begin{tabular}{|c|l|c|}
\hline No & \multicolumn{1}{|c|}{ Komponen Yang Diamati } & $\begin{array}{c}\text { Hasil Persentase } \\
\text { Siklus II }\end{array}$ \\
\hline 1 & Siswa yang hadir pada saat proses pembelajaran & $100 \%$ \\
\hline 2 & Siswa yang serius dalam menerima pembelajaran & $92,59 \%$ \\
\hline 3 & $\begin{array}{l}\text { Siswa yang melakukan kegiatan lain pada saat } \\
\text { Pembelajaran }\end{array}$ & $7,41 \%$ \\
\hline 4 & $\begin{array}{l}\text { Siswa yang belum memahami materi yang } \\
\text { diajarkan }\end{array}$ & $7,41 \%$ \\
\hline 5 & $\begin{array}{l}\text { Siswa yang aktif bertanya pada guru mengenai } \\
\text { materi pembelajaran }\end{array}$ & $25,93 \%$ \\
\hline 6 & $\begin{array}{l}\text { Siswa yang aktif membantu temannya dalam } \\
\text { pemecahan masalah materi metode jarimatika }\end{array}$ & $18,52 \%$ \\
\hline 7 & $\begin{array}{l}\text { Siswa yang mampu mengerjakan dan } \\
\text { menyelesaikan soal-soal latihan }\end{array}$ & $92,59 \%$ \\
\hline 8 & Siswa yang membutuhkan bimbingan guru dalam & $7,41 \%$ \\
\hline
\end{tabular}


Adapun deskripsi aktivitas siswa pada siklus II diperoleh bahwa dari 27 siswa kelas IV.A MI DDI 1 Palopo setelah diterapkan pembelajaran matematika materi perkalian melalui metode jarimatika pada siklus II kehadiran siswa mencapai $100 \%$, siswa yang serius dalam menerima pembelajaran 92,59\%, siswa yang melakukan kegiatan lain pada saat pembelajaran dan siswa yang belum memahami materi yang diajarkan $7,41 \%$, siswa yang aktif bertanya pada guru mengenai pembelajaran $25,93 \%$, siswa yang aktif membantu temannya dalam pemecahan masalah materi metode jarimatika 18,52\%, siswa yang mampu mengerjakan dan menyelesaikan soal-soal latihan mencapai $92,59 \%$, dan siswa yang membutuhkan bimbingan guru dalam menyelesaikan tugas latihan $7,41 \%$.

b) Deskripsi hasil belajar atau evaluasi siswa

Pada siklus II ini dilaksanakan tes hasil belajar di akhir pembelajaran dengan mengerjakan soal-soal latihan yang diberikan oleh peneliti kepada siswa yang mengikuti pembelajaran. Pada siklus ini hampir sama dengan siklus sebelumnya, hal ini dilakukan untuk melihat sejauh mana peningkatan hasil belajar matematika siswa materi perkalian setelah diterapkannya metode jarimatika pada siklus sebelumnya. Dan data hasil evaluasi/hasil belajar siklus II dalam kegiatan pembelajaran materi perkalian setelah penerapan metode jarimatika pada siklus I dapat dilihat pada tabel berikut:

\section{Tabel 7}

Hasil Evaluasi Siklus II Setelah Penerapan Metode Jarimatika

\begin{tabular}{|c|c|c|c|}
\hline \multicolumn{2}{|r|}{ Nomor } & \multirow{2}{*}{ Nama Murid } & \multirow{2}{*}{ Skor } \\
\hline Urut & NIS & & \\
\hline 1 & 111273730001120014 & Muh. Ari Sigit & 100 \\
\hline 2 & 111273730001120024 & Muhammad Ayub & 100 \\
\hline 3 & 111273730001130011 & Bella Vista & 100 \\
\hline 4 & 111273730001130017 & Firman Syahputra Sandy & 100 \\
\hline 5 & 111273730001130020 & Halila & 100 \\
\hline 6 & 111273730001130071 & Ipa Ainun Bilqisti & 100 \\
\hline 7 & 111273730001130027 & Kasmita & 100 \\
\hline 8 & 111273730001130029 & Mariani & 100 \\
\hline 9 & 111273730001130031 & Muh. Abhy & 100 \\
\hline 10 & 111273730001130032 & Muh. Afdal Zul Arsil & 100 \\
\hline 11 & 111273730001130038 & Muh. Isal Sudirman & 100 \\
\hline 12 & 111273730001130073 & Muh. Rahman & 100 \\
\hline 13 & 111273730001130046 & Mustajaab Arrahman & 100 \\
\hline 14 & 111273730001130069 & Multazan Fihil Nizan & 100 \\
\hline 15 & 111273730001130049 & Nur Afni & 100 \\
\hline 16 & 111273730001130050 & Nurfadillah Sari & 100 \\
\hline 17 & 111273730001130051 & Nurul Aulia & 100 \\
\hline 18 & 111273730001130052 & Perawati Safitri & 100 \\
\hline
\end{tabular}




\begin{tabular}{|l|l|l|l|}
\hline 19 & 111273730001130058 & Rihan Vareza & 100 \\
\hline 20 & 111273730001130061 & Salsabilah & 100 \\
\hline 21 & 111273730001130062 & Sri Rahayu & 100 \\
\hline 22 & 111273730001130063 & St. Nurasyiah & 100 \\
\hline 23 & 111273730001130065 & Syahrul & 100 \\
\hline 24 & 111273730001130077 & Yulia Ramadhani & 100 \\
\hline 25 & 111273730001130072 & Ummul Safna Ihtizan & 100 \\
\hline 26 & 111273730001130082 & Nadine Livhia & 100 \\
\hline 27 & 111273730001130087 & Muh. Ibnu Khaldun Manangalu & 100 \\
\hline
\end{tabular}

Dapat disimpulkan bahwa dari tabel diatas dapat diketahui mulai dari hasil observasi aktivitas siswa dan hasil evaluasi setelah penerapan metode jarimatika pada siklus I yang direfleksi lanjut ke siklus II diketahui bahwa ada peningkatan yang sangat baik pada hasil observasi aktivitas siswa dan hasil evaluasi setelah penerapan metode jarimatika pada siswa kelas IV.A MI DDI 1 Palopo dibanding dengan siklus I dan sebelum penerapan metode jarimatika. Dari data diatas kita dapat melihat hasil evaluasi pada siklus II ini sangat memuaskan hingga semua siswa pada kelas IV.A MI DDI 1 Palopo mencapai nilai 100 walaupun masih ada siswa yang membutuhkan bimbingan guru dalam mengerjakan soal-soal latihan.

Apabila nilai kemampuan siswa dikelompokkan dalam lima kategori maka hasil tes siklus II dipaparkan sebagai berikut:

\section{Tabel 8}

Kategorisasi Tes Hasil Belajar Siswa Kelas IV.A MI DDI 1 Palopo Pada Siklus II Setelah Penerapan Metode Jarimatika

\begin{tabular}{|c|c|c|c|}
\hline Rentang Skor & Kategori & Frekuensi & Persentase \\
\hline $0-54$ & Sangat Kurang & 0 & $0 \%$ \\
\hline $55-64$ & Kurang & 0 & $0 \%$ \\
\hline $65-74$ & Cukup & 0 & $0 \%$ \\
\hline $75-84$ & Baik & 0 & $0 \%$ \\
\hline $85-100$ & Sangat Baik & 27 & $100 \%$ \\
\hline \multicolumn{2}{|c|}{ Jumlah } & $\mathbf{2 7}$ & $\mathbf{1 0 0 \%}$ \\
\hline
\end{tabular}

Berdasarkan tabel diatas dapat kita lihat bahwa jumlah frekuensi sebanyak 27 siswa kelas IV.A MI DDI 1 Palopo yang pada saat dilakukan tes siklus II ini semua siswa hadir, dan diperoleh bahwa tidak ada siswa yang berada dalam kategori Sangat Kurang, Kurang, Cukup, dan Baik, semua siswa berada dalam kategori Sangat Baik dengan persentase $100 \%$.

Apabila hasil belajar siswa pada siklus II dipaparkan dalam kriteria ketuntasan hasil belajar secara klasikal maka dapat dilihat pada table berikut: 
Tabel 9

Persentase Ketuntasaan Hasil Belajar Siswa Kelas IV.A MI DDI 1 Palopo

Siklus II Setelah Penerapan Metode Jarimatika

\begin{tabular}{|c|c|c|c|}
\hline Rentang Skor & Kategori & Frekuensi & Persentase \\
\hline $65-100$ & Tuntas & 27 & $100 \%$ \\
\hline $0-64$ & Tidak Tuntas & 0 & $0 \%$ \\
\hline \multicolumn{2}{|r|}{ Jumlah } & $\mathbf{2 7}$ & $\mathbf{1 0 0 \%}$ \\
\hline
\end{tabular}

Berdasarkan tabel diatas diperoleh bahwa dari 27 siswa kelas IV.A MI DDI 1 Palopo yang hadir, semua siswa tuntas dalam belajar matematika materi perkalian melalui metode jarimatika dengan persentase mencapai $100 \%$.

4) Tahap Refleksi Siklus II

Tindakan yang dilakukan oleh peneliti pada siklus II setelah dilakukan konsultasi kepada ibu Nasmasari selaku wali kelas IV.A MI DDI 1 Palopo pada tahun ajaran 2016/2017, maka pada siklus ini dilakukan beberapa perbaikan. Diantaranya setelah penerapan metode jarimatika pada siklus II dengan penggunaan model pembelajaran Demonstration dan Expilic Intruction dalam pembelajaran, siswa mulai tertarik dan aktif pada saat pembelajaran materi yang disajikan oleh peneliti dan siswa yang melakukan kegiatan lain mulai mengubah perilakunya menjadi positif. Kemudian siswa mulai aktif membantu temannya dalam pemecahan masalah dan dalam pengerjaan soal LKS yang diberikan oleh peneliti kepada siswa, siswa mulai berhati-hati dan tidak tergesa-gesa dalam penyelesaian soal yang diberikan dan siswa mulai teliti dan cepat dalam pengerjaan serta pengumpulannya sehingga waktu pembelajaran berjalan efisien.

Secara umum selama siklus II kegiatan pembelajaran berlangsung sangat baik, bila ditinjau dari keterlibatan siswa dalam proses pembelajaran dengan penggunaan metode jarimatika pada materi perkalian juga meningkatkan minat dan motivasi belajar siswa terhadap pelajaran matematika, hal ini dapat dilihat dari perubahan motivasi atau aktivitas siswa dalam mengikuti proses pembelajaran dengan pemaparan hasil observasi dan hasil evaluasi pada siklus II yang dapat dilihat pada tabel 4.12 dan 4.13, ini berarti bahwa siswa telah menguasai materi pembelajaran yang artinya dalam siklus II ini nilai prestasi siswa maupun persentase siswa sudah dapat memenuhi indikator kerja dan dikatakan tuntas dengan nilai sangat baik yaitu 100 .

Dari hasil refleksi ini dapat disimpulkan bahwa telah terjadi peningkatan hasil belajar matematika siswa materi perkalian pada siswa kelas IV.A MI DDI 1 Palopo Kabupaten Luwu 
setelah diterapkannya metode jarimatika dalam pembelajaran dan selain itu keaktifan siswa dalam proses pembelajaran juga meningkat.

\section{B. Pembahasan}

Penelitian ini merupakan penelitian tindakan kelas yang menerapkan metode jarimatika, penelitian ini terdiri atas dua siklus dimana tiap siklusnya dilakukan dua kali pertemuan. Penelitian ini membuahkan hasil yang sangat baik yaitu meningkatnya aktivitas positif dan hasil belajar matematika siswa materi perkalian pada siswa kelas IV.A MI DDI 1 Palopo Kabupaten Luwu.

Hasil analisis menunjukkan bahwa sebelum penerapan metode jarimatika materi perkalian dalam pembelajaran matematika, hasil belajar matematika siswa kelas IV.A MI DDI 1 Palopo Kabupaten Luwu masih sangat kurang atau rendah dengan persentase 81,48\% siswa tidak tuntas dan hanya 18,52\% siswa tuntas. Kemudian bila dibandingkan dengan hasil belajar matematika materi perkalian pada siswa kelas IV.A MI DDI 1 Palopo Kabupaten Luwu setelah diterapkan metode jarimatika pada siklus I dan siklus II terlihat adanya peningkatan hasil belajar matematika siswa materi perkalian, data tersebut dapat dilihat pada hasil observasi dan hasil evaluasi siklus I pada tabel 3.8 dan tabel 3.9 serta siklus II pada tabel 4.12 untuk hasil observasi dan tabel 4.13 untuk hasil evaluasi. Pada pemaparan kriteria ketuntasan hasil belajar pada siklus I dengan jumlah siswa yang aktif 27 siswa diperoleh 16 siswa tuntas dengan persentase 59,26\% dan 11 siswa tidak tuntas dengan persentase 40,74\%. Hasil pada siklus I ini belum mencapai Kriteria Ketuntasan Minimal (KKM) yang telah ditetapkan yaitu $\geq 65$, berdasarkan hasil refleksi pada siklus ini penelitian dilanjutkan ke siklus berikutnya yaitu siklus II. Pada siklus II diperoleh berdasar tabel yang telah di paparkan oleh peneliti bahwa semua siswa tuntas dalam pembelajaran matematika materi perkalian dengan penerapan metode jarimatika dengan jumlah 27 siswa hadir dan tuntas dengan persentase 100\% pada siklus II ini dan termasuk dalam kategori sangat baik serta telah mencapai Kriteria Ketuntasan Minimal (KKM) dan siklus pun dihentikan.

Selain itu siswa tidak merasa kaku lagi dalam pembelajaran metode jarimatika dalam proses pembelajaran dan siswa berani mengajukan pertanyaan atau mengemukakan ide-idenya, keberanian siswa untuk maju kedepan dalam menyelesaikan soal-soal latihan dan bertanya pada siklus II semakin meningkat. Dengan demikian, pembelajaran dengan metode jarimatika pada materi perkalian secara nyata memberikan kontribusi positif dalam meningkatkan keterampilan siswa dalam berhitung terutama bagi siswa yang memiliki kemampuan rendah dan membuat siswa senang mempelajari matematika. 


\section{PENUTUP}

Berdasarkan hasil penelitian yang telah dilakukan, maka dapat disimpulkan bahwa, pelaksanaan pembelajaran dengan menerapkan metode jarimatika dapat meningkatkan hasil belajar matematika siswa kelas IV.A MI DDI 1 Palopo Kabupaten Luwu. Hal ini dapat dilihat dari hasil belajar siswa yang mengalami peningkatan yaitu:

1. Hasil belajar matematika siswa kelas IV.A MI DDI 1 Palopo Kabupaten Luwu Tahun pelajaran 2016/2017 sebelum penerapan metode jarimatika materi perkalian hanya sebesar $20 \%$ siswa tuntas dan berada pada kategori sangat rendah.

2. Hasil belajar matematika pada siklus I setelah penerapan metode jarimatika materi perkalian siswa kelas IV.A MI DDI 1 Palopo Kabupaten Luwu Tahun pelajaran 2016/2017 mengalami peningkatan sebanyak 16 siswa tuntas dengan persentase $61,54 \%$ termasuk dalam kategori kurang.

3. Hasil belajar matematika pada siklus II setelah diadakan refleksi dari siklus I dalam penerapan metode jarimatika materi perkalian siswa kelas IV.A MI DDI 1 Palopo Kabupaten Luwu Tahun pelajaran 2016/2017 mengalami peningkatan yang sangat memuaskan dengan jumlah 27 siswa yang hadir mengikuti hasil tes akhir siklus semua siswa tuntas dengan persentase $100 \%$ dan berada pada kategori sangat baik. Selain itu berdasarkan hasil observasi terhadap aktifitas siswa selama proses pembelajaran di setiap siklusnya menunjukkan perubahan siswa ke arah yang lebih positif, baik dari segi kognitif, afektif maupun psikomotoriknya. 


\section{DAFTAR PUSTAKA}

Abdullah, M.K, Metode Belajar Cepat Jarimatika. Cet. I; Jakarta: Sandro Jaya, 2011.

Abdurrahman, Mulyono., Pendidikan Bagi Anak Berkesulitan Belajar. Jakarta: Rineka Cipta, 1999.

Arikunto Suharsimi, Prosedur Penelitian Suatu Pendekatan Praktik. Jakarta: Rineka Cipta, 2006.

Bahri, Djamarah Syaiful, Psikologi Belajar. Cet. III; Jakarta: Rineka Cipta, 2011.

Departemen Agama RI., Al-Qur'an dan terjemahan. Cet. I; Bandung: Mizan Pustaka, 2009.

Dimyati dan Mudjiono, Belajar dan Pembelajaran. Cet. III; Jakarta: Rineka Cipta, 2006.

Furchan Arief, Pengantar Penelitian dalam Pendidikan. Surabaya: Usaha Nasional, 2016.

Hamalik Oemar, Unsur-unsur Belajar Mengajar. Cet. I; Jakarta: PT Rineka Cipta, 2003.

Hasbullah, Dasar-Dasar Ilmu Pendidikan. Jakarta: Raja Grafindo Persada, 2006.

Heruman, Model Pembelajaran Matematika di Sekolah Dasar. Cet. I; Bandung: Rosda Karya, 2007.

Hidayanti Kurnia, Teori Belajar Matematika Menurut Aliran Gestalt. Ponorogo: Cendikia, 2010 .

Istiawati Inayatul Isti'ada, "Perbedaan Antara Prestasi Belajar Matematika dengan Menggunakan Media Jarimatika dan Tanpa Menggunakan Media Jarimatika Pokok Bahasan Berhitung Siswa Kelas I Semester Genap MI Ma'arif Juwonan Wonosobo TA 2006/2007”. Tersedia pada http://Inais.blogspot.com. (Diakses pada tanggal 16 April 2016).

Marsigit, dkk., Pengertian matematika. Jakarta: Bulan Bintang, 2003.

Mulyasa E., Menjadi Guru Profesional. Bandung: Remaja Rosdakarya, 2008.

Peni, Septi Wulandari, Jarimatika. Cet. V; Jakarta: Kawan Pustaka, 2011.

Sabri, H. Ahmad., Strategi Belajar Mengajar dan Micro Teaching. Cet. I; Jakarta: Quantum Teaching, 2005.

Sawiwati, "Meningkatkan Prestasi Belajar Siswa Kelas III SDN 3 Makarti Jaya Tentang Ciriciri Mahluk Hidup Melalui Metode Demonstrasi”. Skripsi Sarjana Pendidikan, (Palembang: Perpustakaan UT, 2009).

Schimmel, Annemarie. Misteri Angka-angka. Cet. I; Bandung : Pustaka Hidayah, 2004.

Simanjuntak, Lisnawati, dkk. Metode Mengajar Matematika I. Cet. I; Jakarta: Rineka Cipta, 1993. 
Slameto, Belajar dan Faktor-faktor yang Mempengaruhinya. Edisi Revisi, Cet. III; Jakarta: Rineka Cipta, 1995.

Soejanto Agoes, Bimbingan Ke Arah Belajar yang Sukses. Cet. IV; Jakarta: Rineka Cipta, 1995.

Subarinah Sri, Kamus Besar Bahasa Indonesia. Cet. III; Ed. Ke-2; Jakarta: Balai Pustaka, 2006.

Sudjana, Nana. Penelitian Hasil Proses Belajar Mengajar. Cet. II; Bandung: Remaja Rosdakarya, 2006.

Sugiono, Statistika Untuk Penelitian. Cet. XVIII; Bandung, 2011.

Suharsimi, et.al., Penelitian Tindakan Kelas. Cet. X; Jakarta: PT. Bumi Aksara, 2011.

Sujarwo, "Efektifitas Pembelajaran Teknik Jarimatika Terhadap Hasil Belajar Matematika Siswa Kelas III Madrasah Ibtidaiyah Nahdatul Wathan Desa Tawakua Kecamatan Angkona Kabupaten Luwu Timur”. Skripsi, (Palopo: STAIN Palopo, 2013).

Sunar Dwi, Metode Jarimatika. Jakarta: PT Rineka Cipta, 2009.

Uno, Hamzah B., Orientasi Baru Dalam Psikologi Pembelajaran. Cet. I; Jakarta: Bumi Aksara, 2006.

User, Moh Usman, dkk. Belajar Mengajar. Cet. II; Bandung: Remaja Rosdakarya, 2006.

Widyaningrum, Retno., Upaya Mengatasi Kesulitan Belajar Matematika Pada Anak Usia 613 Tahun. Vol. 6; Ponorogo: Cendikia, 2008. 